Jan Paweł II. Posługa myślenia, t. 2, red. ks. B. Kastelik, A. Krupka, ks. R. Woźniak, Kraków 2015, s. 141-161

(Studia nad Myślą Jana Pawła II, 17).

DOI: http://dx.doi.org/10.15633/9788374384933.09

Inga Mizdrak

\title{
ŚWIATŁOCIENIE WOLNOŚCI W FILOZOFII KAROLA WOJTYŁY I JÓZEFA TISCHNERA
}

„Ocalenie”, „zguba”, „przebudzenie”, „dramat”, „szyderstwo”, „wspaniałomyślność, „nieredukowalność”, „przyswojenie”, „odswojenie”, „napięcie”, „prześwit”, „upadek”, „odnowa”, „zapaść”, „transcendencja”, „immanencja”, „spełnienie”, „niespełnienie” - wyrażenia te odsłaniają dialektykę wielu fenomenów uwydatniających specyfikę wolności, obecną w dwóch prezentowanych w niniejszym studium filozoficznych podejściach, które we współczesną antropologiczną debatę wnoszą inspirujące spojrzenie na pradawny problem człowieka. Wolność bowiem immanentnie związana jest z ludzką kondycją, zarówno w świecie zewnętrznym (gdzie człowiek permanentnie zostawia jej ślady), jak i w wewnętrznej strukturze człowieka (gdzie nieustannie wolność daje o sobie znać, wzmagając w człowieku rozmaite wysiłki, budząc w nim dylematy czy powodując różnorodne napięcia). Wydaje się, że w odniesieniu do wolności trzeba zająć jakieś stanowisko, gdyż „nie jest [ona] jednym z tych aksjologicznie neutralnych faktów, które wciska nam w oczy matematyczne przyrodoznawstwo. Wolność fascynuje i napawa lękiem, dlatego zmusza, by nasza postawa wobec niej nie była nieokreślona"' ${ }^{1}$

Karol Wojtyła i Józef Tischner, zaproszeni w niniejszych rozważaniach do zabrania głosu w kwestii wolności, biorąc pod uwagę ich cały filozoficzny dorobek, z pewnością mogliby zostać nazwani filozofami wolności. Wolność bowiem, jako problem i główne pytanie w dookreślaniu człowieka, znajduje się we wszystkich najważniejszych dziełach myślicieli. Dlatego też na tej podstawie można podjąć próbę pewnej syntezy w oparciu o najważniejsze teksty

\footnotetext{
$1 \quad$ J. Tischner, Świat ludzkiej nadziei, Kraków 1975, s. 149.
} 
filozoficzne myślicieli (a nie wszystkie, w których zagadnienie wolności się pojawia). Koncepcje wolności Wojtyły i Tischnera nie są „wykończone”, stąd i podjęta próba syntezy raczej ma zakreślić pewien horyzont poznawczy, aniżeli stać się jakąś sprecyzowaną wykładnią. Zabieg ograniczenia obecnych rozważań do niektórych wątków filozoficznych staje się koniecznością w obliczu złożoności, wielowymiarowości i poziomu skomplikowania problematyki wolności. Porównanie całego naukowego dorobku obu myślicieli wymagałoby osobnej monografii. Stąd zostaną pominięte wątki społeczne, które stanowią ogromny materiał badawczy w analizie wolności, a także religijne, zestawiające wolność skończoną z nieskończoną wolnością Boga.

Wybór i selekcję aspektów, jakie zostaną omówione w niniejszym studium, być może trzeba by uzupełnić o kolejne, których z przyczyn ramowych nie uda się rozwinąć, a które ukazałyby jeszcze pełniej, co to znaczy być wolnym. Mając tego świadomość, podjęto próbę przyjrzenia się temu, jak wolność ukonstytuowana jest w człowieku, w jakim horyzoncie się odsłania i w jakiej perspektywie spełnia. Po głębszej analizie tekstów obu filozofów można zauważyć, iż występujące różnice pomiędzy nimi tylko na pierwszy rzut oka wydają się dość radykalne. Sądzę, że mimo odmiennego spojrzenia na wolność, jest możliwe wydobycie tego, co wspólne, co łączy i synchronizuje dwa podejścia.

Filozoficzna formacja Wojtyły i Tischnera wywodzi się z różnych tradycji i stanowisk intelektualnych. Filozofowie posługują się odmiennymi językami, pojęciami teoretycznej refleksji i sposobami definiowania głównych kategorii antropologicznych. Tischner był spadkobiercą zasadniczo Husserla, Schelera, Rosenzweiga, Levinasa, Ricouera, Wojtyła zaś - św. Tomasza z Akwinu, św. Jana od Krzyża, Kanta i Schelera.

Z pewnością zasadnicza różnica na poziomie metodologii filozoficznego dyskursu obu myślicieli ukazuje się w stosunku do tomizmu. Wojtyła przyjmuje metafizykę tomistyczną w sposób naturalny, jest jej wierny i konsekwentnie włącza ją w swe analizy, choć z czasem coraz bardziej fascynuje go neotomizm ze szkoły lowańskiej otwierający się na filozofię współczesną (w tym na fenomenologię, którą Wojtyła ostatecznie zastosował w opisie człowieka). Myśliciel szukał sposobu zastosowania filozofii klasycznej w dopełnieniu jej fenomenologią. Ów styk metafizyki tomistycznej oraz fenomenologii upatrywał przede wszystkim w ich wzajemnej relacji oraz wyjaśnianiu wewnętrznej struktury osoby jako doświadczającej oraz przeżywającej siebie i świat. Tischner natomiast stosował podejście fenomenologiczno-hermeneutyczne, krytykując tomizm za nieprzydatność jego aparatury pojęciowej do opisu 
doświadczeń ludzi, którzy przeszli przez Gułag i Oświęcim² ${ }^{2}$ Trzeba dodać, że Tischner tomizmu nie dezawuował, lecz raczej wskazywał, iż metoda analityczno-dedukcyjna tego systemu nie jest jedyną możliwą drogą rozświetlania prawdy o rzeczywistości, a nadto, że sposób wyprowadzania ludzi z doxy za pomocą pojęć wypracowanych w tomizmie odseparowuje od uwzględnienia tego, co subiektywne, co bezpośrednio jawi się w konkretnym doświadczeniu danego człowieka.

Pozostawiając jednakże metodologię i źródła myśli Wojtyły i Tischnera nieco w tle, więcej uwagi należy poświęcić postulatom i głównym ideom, które stanowią przedmiot niniejszej pracy, by wejść w obszar współmyślenia z inspirującymi koncepcjami wolności obu filozofów, gdyż odmienne intelektualne drogi, jakie wybrali, podprowadzały ich w gruncie rzeczy do tego samego celu: do zgłębiania przez nie tajemnicy człowieka i jego kondycji w świecie. Niejednokrotnie, jak się okaże, metody te prowadziły do zbieżnych konstatacji, dopełniających się wzajemnie. Mówiąc o podstawowych strukturach człowieka i świata dwoma odmiennymi głosami, filozofowie ci spotykają się na płaszczyźnie centralnych kategorii, które stanowią zręby ich filozoficznych inspiracji. Myślę tu zwłaszcza o kategoriach osoby, wolności, miłości, odpowiedzialności, wspólnocie, solidarności i uczestnictwie, wzajemności, pracy. Widać wyraźnie w podejściu obu, iż problemy te interesowały ich przez ich całe życie, nie tylko naukowe, ale i duszpasterskie, religijne, osobiste.

Zderzając dwa sposoby patrzenia na wolność, nie da się nie zauważyć, że Wojtyła jakby dochodzi do fenomenu wolności z wnętrza opisu człowieka, a analizy Tischnera często wyłaniają się z wnętrza metafor, symboli i obrazów literackich, dopełniających fenomenologiczne opisy o nowe sensy i znaczenia. Co ciekawe, ani jeden, ani drugi sposób nie roni niczego z ważności debaty nad wolnością człowieka, natomiast każdy wyjawia kolejne „poziomy”, czy „warstwy” wolności, tym samym problematyzując wiele zagadnień domagających się dookreślenia.

\footnotetext{
2 Lista zarzutów względem tomizmu znalazła się w takich publikacjach Tischnera, jak: Schyłek chrześcijaństwa Tomistycznego, „Znak” 1970 nr 1 (187), s. 1-26, Tomizm bez mitologii, „Tygodnik Powszechny” 1977, nr 17, s. 1, 2. Krytycznym opracowaniem sporu Tischnera z tomizmem zajmuje się Michał Zembrzuski w Cienie bez jaskini - spór M. Gogacza i J. Tischnera o charakter filozofi, [w:] Mieczysław Gogacz. Filozofia i mistyka, red. I. Andrzejuk, T. Kilmski, Warszawa 2012, s. 99-114 oraz A. Wilczek, W poszukiwaniu prawdy o człowieku. Spór Księdza Józefa Tischnera z Tomizmem, „Czasopismo Filozoficzne” nr 4/5 - październik 2009, s. 52-72.
} 
Tischner pierwotnego sensu wolności szuka nie tyle we wnętrzu pojedynczego człowieka, ile w przestrzeni międzyludzkiej. Wojtyła odwrotnie: najpierw praesens wolności odsłaniany jest w konkretnym indywiduum, a dopiero później można go odszukiwać w międzyludzkiej rzeczywistości. Obydwaj podkreślają aksjologiczny i etyczny charakter wolności, ale inaczej patrzą na jej ontologiczny sens (zwłaszcza w wydaniu św. Tomasza z Akwinu).

Tischner o wolności w znaczeniu filozoficznym powie najwięcej poprzez filozofię spotkania i dialogu, gdzie przede wszystkim odsłoni się dramatyczny sens wolności: wolności jako rzeczywistości osadzonej w nieustannym napięciu dobra i zła. Wojtyła zaś o wolności w znaczeniu filozoficznym powie najwięcej za pomocą metafizyki klasycznej i fenomenologii, gdzie sens wolności uwydatni się przede wszystkim w samostanowieniu. Poprzez czyn, samostanowienie Wojtyła starał się ukazać wyraźniej, że człowiek jako osoba, to ktoś, a nie coś; to ktoś, kto jakimś się staje w wolności.

Z pewnością obu intryguje człowiek, obaj widzą w nim piękno, a nawet postrzegają go jako dzieło sztuki (jako epifanię Bożej kreacji), ale akcentują w odmienny sposób to, co w człowieku ma wymiar podstawowy. W koncepcji Wojtyły czyn odegra kluczową rolę w unaocznianiu osoby, natomiast u Tischnera $J a$ odsłoni się przede wszystkim jako podmiot wartości (Ja aksjologiczne).

Obaj filozofowie, mając świadomość trudności w definiowaniu wolności, stają na stanowisku, że wolność jest obecna w doświadczeniu: wolność sama daje się doświadczyć i w tym doświadczeniu poznawczo i istotowo uchwycić (a może, jak mówi Tischner najłatwiej doświadczać jej utraty). Jeśli wolność jakoś „przebłyskuje” w doświadczeniu, to odsyła zrazu do tego, który doświadcza, do podmiotu doświadczenia i podmiotu doświadczającego siebie, świat, drugiego człowieka.

Trzeba pamiętać, że u Wojtyły doświadczenie rozpatrywane jest w aspekcie świadomości i działania podmiotu. Wojtyła twierdzi, że przedmiotem doświadczenia jest każdy dla siebie w sposób jedyny i niepowtarzalny, a inny, który nie jest mną, w swej niepowtarzalności jest równie radykalnym, odmiennym ode mnie Ja. Powodem niewspółmierności jest właśnie doświadczenie wewnętrzne, którym obdarzona jest każda osoba, gdyż jest ono nieprzenośne poza własne $J a$. Zdaniem Wojtyły zatem najpierw $J a$ w doświadczeniu odkrywa własną wolność i doświadcza jej, a dopiero w następnej kolejności odkrywa wolność innego. Według Tischnera zaś w zasadzie istnieje tylko jedno rzetelne doświadczenie: doświadczenie drugiego. Doświadczając drugiego, docieramy do jego świadectwa i świadectwa o nim. Docieramy do nagości jego twarzy, pragnącej przyjęcia, twarzy łaknącej sprawiedliwości, 
miłości i prawdy, twarzy zatroskanej swoim losem, twarzy niejednokrotnie uwikłanej w kłamstwo, „zniewolonej”, jawiącej się jako nieautentyczna, skrywająca coś za maską, oddalająca drugiego od siebie. W przekonaniu Tischnera pierwszą doświadczoną wolnością nie jest wolność doświadczającego, lecz wolność innego, przejawiająca się na poziomie aksjologii i agatologii ${ }^{3}$. Dlatego fundamentalne $\mathrm{z}$ punktu widzenia dociekania pytanie: czym jest wolność? wybrzmiałoby u myślicieli nieco inaczej. Wojtyła zapyta, co jest istotą wolności człowieka, w jakim horyzoncie wolność się spełnia. Tischner zaś doda, co jest istotą wolności, której człowiek doświadcza w sobie i czy doświadczana wolność jest tą, do której człowiek został powołany, a także jakie ślady ta wolność pozostawia w człowieku i w jego świecie ${ }^{4}$.

Prześwit, przejawy i odsłony wolności uwydatnia wnętrze człowieka. Tam rozgrywa się wolność i być może najwyższa stawka w życiu człowieka: ocalenie wolności, a przez nią siebie. Ocalenie nie musi oznaczać zrazu wyemancypowania podmiotu, który w swoim egzystencjalnym trwaniu jest, mówiąc po sartre’owsku, „skazany na wolność”, lub też który jest skierowany na absolutne, niczym nieskrępowane działanie, panowanie, dysponowanie sobą. Ocalenie nie musi również oznaczać ucieczki przed jakąś rzeczywistością, w tym wypadku wolnością. Ocalenie, o którym rozprawiają Wojtyła i Tischner, jawi się jako rodzaj ochrony własnego człowieczeństwa, walki o nie, w znaczeniu zarówno etyczno-aksjologicznym, jak i agatologicznym. Takie ocalenie mogłoby oznaczać zarówno ustrzeżenie się w porę przed zgubą (np. przed jakimś zniewoleniem, czy to zewnętrznym, czy wewnętrznym, lub przed popadnięciem w zło, w matnię kłamstwa i nieprawdy), jak i wyjście na nową drogę wewnętrznej przemiany, albo także zabezpieczenie się przed nieocaleniem, a więc swoistym unicestwieniem. Ocalenie może w końcu symbolizować rodzaj wyswobodzenia, oswobodzenia, uwolnienia się z dotychczasowej rzeczywistości, a może i nawet tożsamości na rzecz nowej (dodajmy: rezygnacji ze zła, które się dotąd wybierało i czyniło swoim).

Kiedy Wojtyła mówi o samospełnieniu człowieka, a Tischner o „wygraniu siebie”, obaj wskazują na powyższe aspekty ocalenia siebie poprzez wolność. Obu zależy w gruncie rzeczy na osiągnięciu przez człowieka optimum, które na drodze etycznej oznacza pełnię człowieczeństwa, na drodze zaś religijnej relacji z Bogiem dotyczy i dotyka problemu zbawienia. Co to jednak znaczy osiągnąć pułap samospełnienia, czym jest „wygranie siebie”,

\footnotetext{
$3 \quad$ Zob. J. Tischner, Filozofia dramatu, Kraków 2006, s. 56.

$4 \quad$ Por. tenże, Świat ludzkiej nadziei, Kraków1975, s. 147 i 150.
} 
skoro nieusuwalnie toczy się dramat dobra ze złem, w którym człowiek do samego dna jest zanurzony i im bardziej chciałby się z niego wyrwać, tym głębiej go doświadcza. Dramat nie tylko toczy się na poziomie bipolarnych rzeczywistości dobra i zła, ale dramatyczne jest i samo pytanie, kim jest człowiek, a precyzyjniej: kim jestem ja jako ten oto człowiek, który coś ze swoją wolnością ma zrobić. Wojtyła i Tischner doskonale zdają sobie sprawę z pulsującej dramatyczności, leżącej u źródeł wolności i zagrożeń płynących z jej utraty. Tischner wprost osadza wolność w horyzoncie agatologicznym, w którym na śmierć i życie toczy się spór światła z ciemnością i w efekcie zakłada on albo zbawienie, albo potępienie człowieka. Stawka zatem obecna $\mathrm{w}$ tej alternatywie jest najwyższa, jaka w wolności i poprzez nią uwydatnia się w życiu człowieka. Wojtyła raczej rozpatruje wolność w aspekcie dramatu, łącząc je $\mathrm{z}$ napięciem, jakie jest obecne w człowieku, $\mathrm{i}$ to nie tylko pomiędzy tym, kim jest, a kim powinien być, ale też pomiędzy spełnieniem a niespełnieniem człowieka, przy czym spełnienie rozumiane byłoby tu jako rodzaj „zbawienia” w wyborze dobra i prawdy, a niespełnienie jako rodzaj autozniszczenia i autozniewalania się poprzez wybór zła. Widać wyraźnie, jak z głównych filozoficznych analiz wydobywa się pytanie o to, kim jest $J a$ w polu odpowiedzialności, kim jest $J a$ w horyzoncie prawdy i kim jest $J a$ w sumieniu w odniesieniu do miłości.

Zasygnalizowania wymaga podanie podstawowych różnic, które w pewien sposób dystansują od siebie wizje tego, kim jest człowiek w perspektywie poszczególnych aspektów, na jakich koncentrują się obaj myśliciele, aby następnie odszukać i odsłonić punkty, na styku których spotyka się ich myślenie. Ukazanie właśnie podobieństw wydaje się być pomocne w tropieniu „właściwości” wolności, jej zasadniczego znaczenia i fundamentalnych przejawów.

Różnice między myślicielami, jak zaznaczono na początku niniejszych rozważań, nie stanowią antynomicznej przepaści separującej rozstrzygnięcia. Różnice są, ale nie ma rozziewu w przypadku rozumienia rdzenia, do którego $\mathrm{w}$ analizie wolności będą się odwoływali. Ponadto niektóre $\mathrm{z}$ różnic wydają się być wyraziste, inne zaś nieostre, a skoro tak, to można przypuszczać, iż obaj myśliciele mówią o tym samym po prostu różnymi językami. Przez to i sama kwestia wolności polaryzuje się na gruncie filozofii człowieka, a także odsłania jako rzeczywistość dynamiczna.

Podstawowa odmienność zaznacza się już w doświadczeniu. Wojtyła powie, iż najpierw Ja w doświadczeniu odkrywa i doświadcza swej wolności: „Człowiek dany jest w doświadczeniu (przede wszystkim w samo-doświadczeniu) 
jako osoba poprzez samostanowienie" ${ }^{5}$. Tischner skonstatuje dokładnie na odwrót; pierwszą doświadczoną wolnością jest wolność innego, gdyż „wolność nie włazi w człowieka po przeczytaniu książek. Wolność przychodzi po spotkaniu drugiego wolnego człowieka. Kiedy niewolnik spotka człowieka wolnego, albo go za tę jego wolność znienawidzi, albo sam staje się wolny"6. Wyakcentowane są różne poziomy: indywiduum doświadczające siebie i innych (Wojtyła) oraz relacja podmiotów, w której wolność staje się wydarzeniem, rzeczywistością rozgrywającą się między ludźmi (Tischner). Do takich stwierdzeń doprowadziły obu przyjęte przez nich założenia antropologiczne. Wojtyła staje na stanowisku, że Ja ontologicznie nie konstytuuje się przez Ty, lecz w swym byciu jest suppositum (podmiotem istnienia i działania) oraz istotą nieprzekazywalną, alteri incommunicabilis (nieprzenośną poza własne ,ja”), co nie oznacza, że jest bytem niekomunikowalnym. Zaznacza pierwszeństwo podmiotu osobowego przed wspólnotą, ale również podkreśla, iż człowiek również z innymi współbytuje, współdziała i może się również poprzez innych spełniać. Tischner natomiast wychodzi od stwierdzenia, że pierwsza jest relacja, spotkanie osób, w którym dochodzi do wzajemnego zadania pytania i podania jakiejś odpowiedzi na zagadnięcie. Zatem do mowy o poszczególnym „Ja” dochodzi jakby w drugiej kolejności, później. Pierwsza jest relacja, to ona wydobywa na jaw Ja i Ty. Tischner nie radykalizuje tej kolejności, rezygnując zarówno z „transcendentalnego subiektywizmu” Husserla, jak i "genetycznego obiektywizmu” Gabriela Marcela czy Martina Bubera (jak sam je określa) i proponuje drogę pośrednią (nie idąc drogą ani od Ja do Ty ani od Ty do $J a)$ wyrażającą się w zdaniu: „wiem, że mnie rozumiesz, więc jesteśmy”7.

Istotna różnica między myślicielami odsłania się na poziomie odmiennego sposobu definiowania wolności. Wojtyła sądzi, że wolnością par excellance jest samostanowienie człowieka, Tischner uważa, iż wolność to sposób istnienia dobra.

Samostanowienie według Wojtyły stanowi istotę wolności człowieka. Nie sprowadza się ono do wymiaru przypadłościowego, lecz przynależy do wymiaru substancjalnego osoby: jest to wolność człowieka, a nie tylko wolność woli w człowieku. Jak podkreśla Wojtyła, w pojęciu samostanowienia zawarty jest twórczy charakter wolności, ale przede wszystkim samego człowieka,

\footnotetext{
$5 \quad$ K. Wojtyła, Osoba i czyn, Kraków 2000, s. 153.

6 A Michnik, J. Tischner, J. Żakowski, Między panem a plebanem, Kraków 1995, s. 290.

7 Rozwinięciem tej kwestii Tischner zajmuje się w Filozofii dramatu, Kraków 2006, na s. $219-222$.
} 
który nie tylko jest sprawcą swoich czynów, ale przez te czyny zarazem w jakiś sposób tworzy siebie samego, konstruując etyczny kształt własnego człowieczeństwa. Warunki samostanowienia określone zostają poprzez struktury samopanowania i samoposiadania siebie. Aby móc stanowić, trzeba najpierw jakoś siebie posiadać i sobie panować. Stanowić „można tylko o tym, co się realnie posiada. Może zaś stanowić tylko ten, kto posiada. Człowiek stanowi sam o sobie wolą, gdyż sam siebie posiada. Równocześnie zaś wola, każde rzeczywiste «chcę» ujawnia, potwierdza i urzeczywistnia to samo-posiadanie właściwe tylko osobie - fakt, iż jest ona sui iuris" ". Oznacza to, że kiedy wraz z ludzkim "chcę", czyli z pewnym uformowanym aktem, konstytuuje się samostanowienie, to samoposiadanie takie konstytuowanie umożliwia. Człowiek musi siebie najpierw faktycznie „mieć”, aby móc stanowić o sobie. Nie tylko jednak powinien siebie mieć, ale i również sobie panować. Wojtyła pisze: „[...] oto osoba jest $\mathrm{z}$ jednej strony tym, kto panuje, panuje nad sobą samym, z drugiej zaś strony tym, nad kim ona sama panuje" . Nie tyle chodzi o panowanie nad instynktami, uczuciami, pożądaniami, ile o coś bardziej podstawowego, obecnego w strukturze człowieka. Człowiek bowiem może sobie panować, a zatem rozporządzać sobą w sposób wyłączny i na wyłączność. Zaznacza się podwójnych charakter „zarządzania” sobą, tzn. względem innych, ale naprzód względem samego siebie. Ujawnia to także wyraźnie przedmiotowość $J a$, czyli to, iż „W czynie poprzez samostanowienie osoba jest dla siebie samej przedmiotem, i to poniekąd przedmiotem pierwszym, czyli najbliższym" ${ }^{10}$.

Tischner w odmienny sposób ujmuje wolność, definiując ją jako sposób istnienia dobra, sądząc, iż tylko dobro jest naprawdę wolne. Mieć udział zatem w dobru oznacza, że uprzednio należy to dobro wybrać, a wybrać dobro to nie tylko zaafirmować je, ale przyjąć, przyswoić, uczynić swoim. Innymi słowy przylgnąć do niego, „człowiek jest wolny dlatego, że w człowieku «dobro ma swój byt»" "1. Preferując drogę wyjścia poza „byt i niebyt”, nie zajmując się ontologicznym znaczeniem wolności, Tischner wskazuje, że istnieje inny poziom, na którym fenomen wolności eksponuje się bodaj najwyraźniej, i tylko na nim można zrozumieć istotę wolności. Poziom agatologiczny jest właśnie tym, na którym odsłaniają się kwestie, wobec których milknie on-

\footnotetext{
$8 \quad$ K. Wojtyła, Osoba i czyn, dz. cyt., s. 152.

Tamże.

10 Tamże, s. 154.

11 J. Tischner, Spór o istnienie człowieka, Kraków 2011, s. 343.
} 
tologia. Według Tischnera być wolnym to znaczy być wolnym w stosunku do dobra i zła.

Wolność dla Tischnera „ma dwa główne promienie...”: jednym kieruje się na zewnątrz siebie, drugim do wnętrza siebie. Dzięki pierwszemu promieniowi wolność dokonuje czegoś w świecie. Dzięki drugiemu wolność dokonuje czegoś w sobie, przede wszystkim dookreśla osobę do dobra lub zła" ${ }^{2}$. Nieprzewidywalność, ryzyko, wahanie podmiotu to pojęcia, które Tischner mocno akcentuje w opisie dramatycznego sensu wolności. Nieprzewidywalność dotyczy przede wszystkim innego, który w swym postępowaniu, wybieraniu może uczynić to, czego ja nie znam i czego nie mogę dowiedzieć się dotąd, aż on tego nie uczyni względem mnie. Owo „względem” jednak ukonkretnia stosunek jednego podmiotu do drugiego i wówczas wolność danego $J a$ „krystalizuje się w horyzoncie i według wolności innego"13. Wolność, jak zaznacza Tischner, jest zdolnością do działań „wewnętrznych”, a nie tylko „zewnętrznych”, przez to zmienia sam podmiot, a raczej to on sam ma możliwość przemienić siebie. Inherentnie wpisana w wolność jest możliwość, potencjalność, która w zaktualizowaniu się dokona rozstrzygnięcia na rzecz tego lub tamtego. Sama też wolność jest czymś inherentnym w strukturze człowieka, stąd może on coś z sobą czynić. Cały sens wolności zasadza się w tym, że polem jej działania i aktualizacji jest osoba. Tischner w wychodzeniu poza kategorie ontologii wskazuje na paradoks wolności. Otóż twierdzi, że trzeba uprzednio być wolnym, aby wybrać wolność, ale nie jest się wolnym, jeśli się nie wybrało wolności. Paradoks ten według myśliciela dowodzi wyjścia z poziomu ontologii i wejścia na poziom agatologii, gdzie wolność to coś "między” podmiotami spotkania. W owo "między” może zaglądnąć dobro, ale i wedrzeć się zło. „Między” jest przestrzenne, ale i samo jest przestrzenią, w której to, co się ukonkretni, wejdzie w relację, tworząc zręby jej wzajemności bądź rozszczepienia, integracji lub dezintegracji, piękna lub brzydoty. Tischner ucieka od abstrahowania, na rzecz zarysowania przestrzeni między podmiotami dramatu, w której podstawową rolę odgrywają struktury: „ku tobie”, „z tobą”, „od ciebie”, „przeciwko tobie”, „obok”, „pod” i ,jak”. W każdej z nich uobecnia się świadomość dobra i zła oraz przeżycia emocjonalne i aksjologiczne. W takiej przestrzeni rodzi się wybór, a ten jest „fundamentalnym wyrazem wolności”"

\footnotetext{
12 Tamże, s. 349.

13 Tamże, s. 350.

14 J. Tischner, Spór o istnienie człowieka, dz. cyt., s. 351.
} 
Należy zarysować pokrótce jeszcze inne różnice między koncepcjami Wojtyły i Tischnera, które uwypuklają bogactwo znaczeniowe oraz sproblematyzowanie kategorii wolności.

Dla Wojtyły kluczowym pojęciem w opisie człowieka jest między innymi „nieredukowalność”. Człowiek jest bytem nieredukowalnym, to znaczy, że w swoim byciu jest niesprowadzalny do innych bytów wewnątrzświatowych oraz że posiada niezbywalną godność i tożsamość, których z samej racji, że się jest człowiekiem, nie da się wyrugować z osoby ani unicestwić. Tym, co o tej nieredukowalności świadczy, jest właśnie wolność człowieka. Poprzez nią eksponuje się nieredukowalność osoby w sposób bodaj najbardziej wyraźny. Znamienne jest, że wolność sama w sobie musi zawierać w sobie coś nieredukowalnego i sama być nieredukowalna, by była faktycznie wolnością, ale też i nieredukowalność zakłada wolność jako coś niezbywalnie oryginalnego i każdorazowo nowego. Wolność jest przejawem nieredukowalności człowieka, gdyż jedynie on posiada zdolność rozstrzygania, za każdym razem nieprzewidywalnego, mogącego zrealizować się w rozmaitych kierunkach. Zatem wolność wskazuje na nieredukowalność osoby i sama w sobie nieredukowalność immanentnie nosi.

Tischner natomiast nie powie, iż poprzez wolność eksponuje się to, że człowiek w swej odrębności jest nieredukowalnym indywiduum (choć powie o odrębności człowieka w omówieniu, czym jest Ja aksjologiczne), natomiast powie, iż poprzez wolność eksponuje się tragiczny i dialogiczny wymiar bytu ludzkiego, i że wolność jest nieustannie zagrożona nie tylko ze strony drugiego, ale również samego $\mathrm{Ja}$, zdolnego do wewnętrznego zniewolenia. Wolność jawi się zatem jako coś do ocalenia, do ochrony. Wolność jest wyzwalaniem siebie, być może permanentnym i w tej paradoksalności nieusuwalnym, a więc toczeniem boju o siebie, o swą ludzką twarz. Wolność to „bycie u siebie”, a więc znaczy tyle, co nie być nie u siebie. Być nie u siebie to nie być sobą, to uciekać od prawdy o sobie, trwać w iluzji i karmić się nią. Nie być u siebie to wyobcowywać się z siebie, udawać kogoś innego, przywdziewać jakąś wykreowaną tożsamość. Jeśli bycie u siebie oznacza niezakłamanie, a kłamstwo jest rodzajem zniewolenia, to być może stan wolności byłby tylko czasowym i nietrwałym doświadczeniem człowieka, skoro w wielu momentach jego życia kłamstwo występuje i na dodatek przywdziewa maskę dobra. Tischner o kłamstwie powie, że jest jedną z najbardziej przewrotnych i „wywrotowych” rzeczywistości człowieka. Dopóki człowiek sam nie opowie się po stronie prawdy, a więc dopóki sam nie uzna kłamstwa za zło, dopóty nieprawda będzie w nim gościć jako specyficzne „dobro”, które w wolności swej (paradoksalnie) 
zdetronizował, zinstrumentalizował i dopuścił, aby zagościło w nim jako "podrobione”, czyli np. zło zracjonalizowane, usprawiedliwione, ukazujące swą „logiczność”. W kłamstwie bowiem dobro zostaje wykoślawione, choć z zewnątrz ma mieć postać pierwotną, tzn. radykalną (gdzie dobro=dobro, a zło=zło, gdzie „tak” znaczy „tak”, „nie” znaczy „nie”). Człowiek, który nie jest u siebie, może mamić zewnętrzny świat i innych, ale nie może mamić siebie. Posiada bowiem samowiedzę o swym zakłamaniu, a więc i de facto o zniewoleniu, które próbuje w kłamstwie „ulogicznić”. Kiedy Tischner mówi, że zło „potrzebuje rąk człowieka żeby się stać”, to należy dodać, iż także dobro takich "rąk" potrzebuje, a więc przede wszystkim wolności, decyzji, która umocuje nowy początek i zakotwiczy człowieka na powrót w prawdzie. Dlatego dramat polega zasadniczo na nieustannym ruchu egzystencji człowieka na osi wolności i zniewolenia, ułudy i prawdy, bycia u siebie i nie bycia u siebie.

Gdzie spotyka się myśl Wojtyły i Tischnera?

Istnieje kilka fundamentalnych obszarów, na gruncie których występuje dość ewidentny styk antropologii Wojtyły i filozofii spotkania Tischnera. O wolności w filozofii chrześcijańskiej nie dywaguje się wszakże w oderwaniu od rzeczywistości osoby, wartości, odpowiedzialności, miłości, dobra, prawdy, sumienia, a przecież obaj myśliciele taką filozofię uprawiali. Każdy $\mathrm{z}$ tych obszarów odwołuje się do niezmiernie złożonej problematyki ontologiczno-etyczno-aksjologiczno-społecznej, a rozpatrywany w kontekście wolności dynamizuje fundamentalne pytanie z zakresu antropologii filozoficznej, mianowicie „kim jest człowiek”. Zarówno Wojtyła, jak i Tischner traktowali te zagadnienia jako szczególnie istotne w analityce ludzkiego "ja” i relacji jednostki $z$ innymi.

Z powodu wysokiego poziomu złożoności analiz (dotyczących owych obszarów), wykraczających daleko poza zasięg i rozmiary niniejszego studium, pewnemu uszczegółowieniu zostaną poddane te, na które po prostu trzeba było się zdecydować, mając pełną świadomość równoważności pozostałych. Dlatego przybliżając kwestię wolności, rozpatrzymy ją pokrótce w aspekcie wartości, decyzji, miłości i odpowiedzialności.

Na płaszczyźnie aksjologii analogia obydwu ujęć odsłania się chyba najwyraźniej. Wolność stanowi wartość dla człowieka, ale i sama jest wartością, a także dzięki niej wartości realizują się w osobie jako bycie moralnym. Wolnością człowiek kieruje się w stronę wartości, wolnością je wybiera, wolnością w końcu je przyswaja. Wolność jako taka sama jest wartością, ale przede wszystkim i najpierw wartością jest człowiek, zarówno w swej osobowej konstytucji, jak i w twórczym charakterze swego bytu w realizacji danych wartości. 
Tischner w Świecie ludzkiej nadziei pisze, że wolność jest wartością dla człowieka, fascynującą i jednocześnie zagrażającą. Dzięki wolności człowiek odkrywa siebie jako byt niepowtarzalny, wyjątkowy i odrębny. Dla Tischnera wolność jest przede wszystkim wartością do osiągnięcia. Doświadczenie wartości w wolności jest podstawowe: „Nie wybieramy, aby wybierać. Wybieramy, aby coś wcielić w życie, a tym, co wcielamy w życie, jest zawsze jakaś wartość. Co prawda nie zawsze potrafimy ją nazwać, ale to nie świadczy przeciwko niej. Wolność nie jest wolnością w świecie, który jest zbudowany Z «czystych możliwości», lecz w świecie prawdy i nieprawdy, szczęścia i nieszczęścia, sprawiedliwości i niesprawiedliwości uczciwości i nieuczciwości, honoru i podłości" ${ }^{15}$. W momencie wyboru wartości dochodzi do przyswojenia ich, a dzięki przyswojeniu dana wartość staje się „moją” wartością, a ja „jej”. Wolność umożliwia przyswojenie: „wolność przyswaja i zarazem pod-

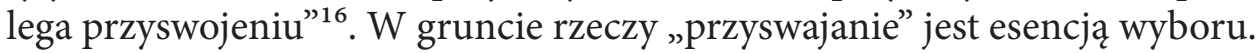
Wybierać to przyswajać wartości, a jeśli człowiek jest wartością, to przyswoić należy siebie. Co znaczy takie autoprzyswojenie? Przyswoić sobie siebie to uczynić „moim własnym”, to dokonać aktu wyboru siebie jako dobra, bo przyswojeniu podlega tylko to, co dobre wedle Tischnera. Wybór siebie jako dobra znaczy, iż „przyswajając sobie to co dobre, tym samym przyswajam siebie dobru"17. Formuła ta jest problematyczna, ponieważ per analogiam można by powiedzieć, iż przyswajając sobie to, co złe, tym samym człowiek czyniłby swoim zło, a więc poniekąd przyswajałby siebie złu i wybierałby siebie jako zło. Jak rozumieć owo przyswojenie u Tischnera, skoro rezerwuje je autor w zasadzie do afirmatywnej strony wyboru pozytywnych wartości, na czele których stoi dobro? Czy rzeczywiście wówczas, gdy człowiek przyswaja sobie to, co złe, dokonuje wyboru siebie jako zła? Nie zawsze zło czyniący zrazu wybrał siebie jako złego, raczej to, że stał się zły, przyszło jakby później: dokonał wyboru zła i dlatego stał się zły, ale nie dlatego stał się zły bo wybrał siebie jako zło. Częściową odpowiedź Tischnera znajdujemy w Sporze o istnienie człowieka, kiedy autor mówi, że człowiek może przyswajać kłamstwo jako coś dla niego „dobrego” na zasadzie logiki odwetu. Wprawdzie kłamstwo nie było dla podmiotu czymś dobrym, ale skoro inny okłamał jego, on też będzie kłamać. Jest wprawdzie kłamcą, ale ze względu na „sprawiedliwy” i uzasadniony, a może i konieczny odwet. Tu „uwikłana w kłamstwo wolność

\footnotetext{
15 Tenże, Świat ludzkiej nadziei, Kraków 1975, s. 157.

16 Tenże, Spór o istnienie człowieka, dz. cyt., s. 357.

17 Tamże.
} 
jest sposobem istnienia dobra we mnie - dobra, które jest «sprawiedliwym odwetem»"18.

Tischner uzupełnia analizę problemu wolności jako przyswojenia o element odswojenia. Wolność może przyswajać lub odswajać. Odswojenie Tischner interpretuje jako „wyrzeczenie się” tego, co było „częścią mnie”. Wyrzeczenie utożsamione zostaje z pozytywnym momentem nowego początku w człowieku. Jest ono przejawem nawracania, przemiany wewnętrznej: „W «nowym początku» osoba wchodzi w inny dramat i konstytuuje siebie «od nowa» jako podmiot tego dramatu" ${ }^{19}$. Nie oznacza to, iż osoba utraciła swą ontologiczną tożsamość, ale że nabrała nowej: aksjologicznie nowej (dopiero horyzont agatologiczny otwiera możliwość początku). Odswojenie nie oznacza zatem utraty czegoś „swojego” lub odejścia od czegoś, co moje, ale raczej odwrócenie się od tego, co do tej pory mnie krępowało i czyniło niewolnikiem. Wraz z odswojeniem to, co przyswojone pierwotnie jako złe, utraciło swą moc przyciągania lub kuszenia, a człowiek odzyskał siebie, znalazł się u siebie, stał się zatem autentycznie wolny.

Wojtyła, podobnie jak Tischner, posługuje się terminem „przyswojenie” w dookreślaniu relacji wolności i wartości. Wraz z dokonaniem się rozstrzygnięcia pojawia się odpowiedź na wartość oraz doświadczenie siebie jako specyficznej wartości. Odpowiedź na wartość ma wymiar niepowtarzalności i jakby radykalnego zamknięcia tego wszystkiego, co stało przed momentem wyboru. Jest to moment osiągnięcia najwyższego pułapu, kulminacji, bo oto wartość przedstawiona została przez człowieka „wy-brana”, a więc jakoś „wzięta” i przyjęta przez niego. Owo „wzięcie” jest jakimś przyswojeniem wartości, ale też i jakimś jej zagarnięciem na własność. Od tej pory wybrana wartość już nie może przestać być moją. Istotne jest to, iż nie różnorodne przedmioty, czy wartości , angażują człowieka i jego wolę, ale on sam angażuje się względem nich" ${ }^{20}$. Wybrana przez jednostkę wartość ma moc wiążącą i wpływającą ostatecznie na nią jako osobę. W momencie rozstrzygania człowiek odpowiada na określone wartości i równocześnie opowiada się za nimi, przesądza zatem tym samym, iż jedne $\mathrm{z}$ nich stały się jego, inne zaś porzucił. W rozstrzygnięciu wpływamy na coś ostatecznie i radykalnie; ostatecznie, gdyż w chwili rozstrzygnięcia coś się dokonuje nieodwracalnie, radykalnie zaś, gdyż przesądzamy o wyborze danej wartości. Rozstrzyganie ma w sobie

\footnotetext{
18 Tamże, s. 361.

19 Tamże, s. 358.

$20 \quad$ K. Wojtyła, Osoba i czyn, dz. cyt., s. 179.
} 
coś arbitralnego. Zawiera w sobie postawienie się po jednej ze stron i nawet gdy wybór poprzedzony jest pewną debatą, jedno $\mathrm{z}$ chceń potencjalnych w końcu staje się aktualne, uhonorowane, zwycięskie nad tymi, które w tym procesie dyskusji motywów jakby straciły na znaczeniu.

Rzeczywistość rozstrzygania ujawnia się w sprawczości osoby, to dzięki niej osoba ujawnia się jako osoba, ale także osoba, jako moralnie dobra lub zła. Rozstrzyganie zdaje się być $\mathrm{z}$ jednej strony momentem dramatycznym (w sensie przedkładania jednych wartości nad drugie, odrzucania bądź afirmowania jednych na rzecz drugich), w którym decyduje się moralna kwalifikacja człowieka, ale z drugiej strony - perspektywą spełnienia osoby. Wedle Wojtyły rozstrzyganie jest pewnym progiem, poprzez który osoba jest wychylona ku dobru. Umiejętność samodzielnego przejścia „progu” okazuje się potwierdzeniem wolności człowieka. Dobro zatem miałoby tę właściwość, że przylgnięcie do niego aktem własnej wolności, pomnażałoby dalsze wybory dobra, ale również, jak mówi Wojtyła: „skutki pierwszego rozstrzygnięcia rozrastają się w zbliżeniu do samego dobra, w obcowaniu z nim czy też zjednoczeniu"21.

Głównym motywem wyboru określonej wartości nie może być tylko sama atrakcyjność wartości, do której się kieruję, ale przede wszystkim musi być „swoiste odniesienie do prawdy, które wnika w intencjonalność chcenia i tworzy jakby jego zasadę wewnętrzną. Prawda rozumiana jest tu jako zasada chcenia (jest obecna wewnątrz woli), najgłębsza racja tego chcenia - stanowi o istocie wolnego wybierania.

Co znaczy wybierać w rozumieniu Wojtyły i Tischnera?

Otóż fundamentalny jest moment samej możliwości oraz podjęcia decyzji. Dla Tischnera dociekającego pierwotnego doświadczenia wolności, ważne stały się rozważania Kartezjusza, a precyzyjniej, formuła „mogę przystąpić do...”, znajdująca się w Medytacjach o pierwszej filozofii. Doświadczenie „mogę" i doświadczenie obecne $\mathrm{w}$ „mogę” stają się polem świadomości podmiotu. Jednostka bowiem wiedząc, (mając świadomość) że może to czy tamto, jest w posiadaniu swoistej mocy, zdolności do zrealizowania czegoś, ale także wie, że ma w sobie samą zdolność wyboru, potencjalność tkwiącą w niej, i tym samym mogącą zaktualizować się w tym lub w tamtym. Nie samo jednak pójście za czymś wskazuje na ową moc i zdolność w człowieku, lecz również nie pójście odznacza się tym samym walorem ważności. Można podążać lub nie brać w czymś udziału, angażować się w coś lub unikać czegoś. W tych momentach uwydatnia się według Tischnera nie tylko sama możliwość przy-

$21 \quad$ Tamże, s. 173. 
stąpienia lub unikania czegoś, ale specyficzna moc takiego przystąpienia/ unikania. Tischner uważa, że w chwili przystąpienia do czegoś dzieje się coś specyficznego w podmiocie i z podmiotem; nabiera on stosunku do siebie i własnego życia $\mathrm{w}$ świecie. Przystąpienie wiąże się z decyzją, a więc $\mathrm{z}$ aktem o złożonym charakterze. W przystąpieniu takim jest inherentnie wpisane jakieś „chcę”, choć trzeba zaznaczyć, iż Tischner wprost o tym nie pisze. Na etapie "mogę" podmiot zdaje się być bowiem niemal absolutnie suwerenny, decyzja jest jeszcze $\mathrm{w}$ „zawieszeniu”, nieokreślona, natomiast w momencie przystąpienia wyraźnie następuje moment położenia akcentu właśnie na to, a nie tamto. To świadczy o wolności człowieka, której nie determinuje ani naturalne skierowanie człowieka na dobro, ani rozum, który przedstawia woli określone alternatywy.

Według Tischnera kartezjańskie pojęcie woli odsłoniło jej faktyczność nie tylko antropologiczną i psychiczną, ale również na wskroś aksjologiczną. Odkrycie aksjologicznego obszaru kartezjańskiego doświadczenia wolności w zasadzie stanowiło dla Tischnera punkt wyjścia dla własnych filozoficznych dociekań, z jednej strony nad naturą wolności „ja aksjologicznego”, które w swoim byciu i działaniu jest autonomiczne, a dzięki wolności „może poczuć się sobą i tylko sobą" ${ }^{22}$, a $\mathrm{z}$ drugiej strony nad dramatyczną stroną tej możliwości „przystąpienia do”, która może zrealizować się albo w perspektywie twórczości albo w perspektywie destrukcji.

W rozważaniach Wojtyły istotną rolę odgrywa troista formuła: „mogę nie muszę - chcę". Najpierw myśliciel wydobywa pierwszy człon i analizuje parę: „mogę - nie muszę", a następnie koncentruje się na opisie "chcę". Jeśli „mogę", to „nie muszę”, nie ma naciskającej determinanty, zniewalającej mój wolny wybór. Możliwość otwiera dopiero przestrzeń do wypełnienia jej skonkretyzowaniem. Ciekawe jest, iż Wojtyła uważa, że „chcę” funkcjonuje niejako między „mogę” a „nie muszę" ${ }^{23}$. Stwierdza, że „chcę” jest kształtowane w owym „między” i stanowi „zdynamizowanie właściwe woli. Wolą nazywamy w człowieku to, co pozwala człowiekowi chcieć" ${ }^{24}$. Wola jest w pełni podległa człowiekowi, a jej wolność, która konstytuuje się w przeżyciu „mogę - nie muszę”, „zawiera się właśnie nade wszystko w zależności od osoby, która «może», a równocześnie «nie musi» posłużyć się nią jako władzą. I dlatego

\footnotetext{
22 J. Tischner, Świat ludzkiej nadziei, dz. cyt., s. 134.

23 Rozwinięcie zagadnienia znajduje się w artykule I. Mizdrak, Spetnić się w wolności, „Zeszyty Naukowe UEK” nr 887 (2012), s. 57-72.

${ }^{24}$ K. Wojtyła, Osoba i czyn, dz. cyt., s. 148.
} 
też pierwszą krystalizacją wolności woli jest pierwotny i elementarny fakt zależności od osoby woli jako władzy samostanowienia tejże osoby" ${ }^{25}$. Wola jest swobodna w swoim ruchu, nie determinuje jej przedmiot ani wartość jako cel. Ona sama wybieraną wartość w pewien sposób „chwyta” i przyswaja na własność.

Ani „chcenie”, ani „mogę - nie muszę” nie wyczerpuje pełnego charakteru woli człowieka. Doświadczenia te są wprawdzie podstawowe zarówno w czynie, jak i w moralności, ale wola wedle Wojtyły odsłania się na jeszcze głębszym poziomie struktury bytowej człowieka. Odsłania się przeto nie jako sama właściwość wewnętrzna czynu człowieka, lecz także jako właściwość wewnętrzna samej osoby. Człowiek „może - nie musi”, ponieważ pierwotnie posiada w sobie taką właściwość, jaką jest w nim wola. „Osoba unaocznia się poprzez wolę, a nie tylko wola poprzez osobę i w osobie"26.

Warto odnotować, że dla Tischnera i Wojtyły kwestia opisywanych figur stanowi niezmiernie ważny i podstawowy warunek dla następnych analiz dotyczących wolności, gdyż są one czymś na wskroś podmiotowym w człowieku i odsyłają do zagadnień świadomości, doświadczenia przeżycia oraz stawania się. W „mogę”, „nie muszę”, „chcę”, człowiek siebie przeżywa i doświadcza własnego $J a$, ale jednocześnie transcenduje siebie w czynie. Spełniając dany czyn, jakoś jednostka spełnia w nim siebie, jakąś się staje (Wojtyła). Ponadto w przestrzeni „mogę przystąpić do" otwiera się perspektywa o bipolarnym charakterze, rozpostarta między dobrem a złem, między tworzeniem własnego człowieczeństwa a jego dewastowaniem (Tischner).

Istnieje jeszcze jedna zbieżność poglądów o wolności w ujęciu Wojtyły i Tischnera, którą dostrzegamy, kiedy przypatrujemy się analizom miłości. Miłość jest bowiem tym fenomenem, który wyjawia i urzeczywistnia: wzajemność, wspaniałomyślność oraz wolność, a ta jest podstawowym warunkiem miłości, jej wyrazicielką i najgłębszym rdzeniem.

Wprawdzie wolność da się pomyśleć w oderwaniu od miłości, ale miłości nie można uwydatnić bez odniesienia do wolności ${ }^{27}$. W miłości nie tylko wybiera się przedmiot miłości (który staje się wybrankiem/wybranką, oblubieńcem/oblubienicą, przyjacielem/przyjaciółką), ale przede wszystkim

$\begin{array}{ll}25 & \text { Tamże, s. } 167 . \\ 26 & \text { Tamże, s. } 151 . \\ 27 & \text { Relacją wolności i miłości zajmuję się w artykule O smaku miłości. Wokół rozważań }\end{array}$ Karola Wojtyły i Józefa Tischnera, „Rocznik Historii Filozofii Polskiej” T. 2/3 (2009/2010) s. 167-198. 
wybiera się dobro, i to nie tylko dobro rozumiane jako podstawowe transcendentalium metafizyczne, lecz dobro, jako wydarzającą się rzeczywistość międzyludzką (np. w konkretnych uczynkach miłosierdzia, ofiary, poświęcenia względem drugiego).

Wojtyła i Tischner w pewnym momencie swoich dociekań mówią jakby jednym głosem: w doświadczeniu miłości rozpoznaję, że drugi, który nie jest mną, jest także jakimś określonym $J a$, mimo, iż różnym ode mnie. Mogę również w takim doświadczeniu odkryć, że drugi jest wartością i że stanowi pewną wartość dla mnie, i to wartość bezwzględną, bez względu na cokolwiek. W miłości obecne są dwa różne $J a$, które w relacji wolności zbliżają się do siebie, lecz nie popadają we wzajemną unifikację. Stają się unią dwóch odrębnych $J a$, są, jak mówi Tischner „różni w inności, inni w podobieństwie”. Stają się zatem bardzo podobni do siebie, ale zachowują własną tożsamość, odmienność. U Tischnera pojawia się figura „nie-bycia wolnym” w miłości, która nie oznacza niewoli, zatracenia własnej tożsamości, lecz afirmację swojej wolności. Jest to akt oddania się, powierzenia drugiemu, zaufania mu i położenia w nim nadziei. Wolność zaangażowana przez miłość staje się twórcza, spełniona, napełniona dobrem.

Podobnie u Wojtyły pojawia się coś w rodzaju „zawieszenia” wolności w miłości. Wolność jest stale obecna na każdym etapie miłości (najpierw miłości jako życzliwości, potem jako upodobaniu, sympatii, przyjaźni, na końcu w oblubieńczym zawierzeniu siebie drugiemu), ale w momencie oddania się drugiemu w miłości jak gdyby dochodzi do tego, że wolność danego Ja siebie właśnie „oddała”, podarowała, powierzyła innemu. Jest to pewien rodzaj „wyzwolenia” z wolności w miłości, wolność jest dla miłości, a nie miłość dla wolności, miłość „wytryska z wolności jak źródło z gleby przeciętej na ukos”28. To, że wolność została „ofiarowana” drugiemu w miłości, nie oznacza, że uległa rozpadowi. Wolność ta wybrała drugiego jako dobro, a zarazem dobro drugiego. W miłości oblubieńczej Ja i Ty staje się wzajemnym $M y$, gdzie dwa oddania stają się jednym, chcąc dobra dla siebie nawzajem.

Wolność w kontekście miłości to jednocześnie warunek miłości, owo: „dla miłości” Wojtyły, jak i „pozwolenie być drugiemu” Tischnera (nawet za cenę cierpienia i utraty miłowanego). Logika wolności i miłości przebiega w zasadzie na drodze nieustannej ofiary z siebie, rezygnacji z egoizmu, udzielania odpowiedzi drugiemu, zatroskania o los i dobro drugiego. Nie jest tak, iż w tej

28 K. Wojtyła, Przed sklepem jubilera, [w:] tegoż, Poezje, dramaty, szkice. Tryptyk Rzymski, Kraków 2007, s. 406. 
logice wszystko przebiega w linii prostej, bez zarysowań, upadków i odejść od dobra. Zarówno Wojtyła, jak i Tischner dostrzegają, jak często w tę logikę wdziera się alogiczne zło, które skądinąd próbuje siebie jakoś „ulogicznić”, by przeciągnąć podmiot na swoją stronę. Wówczas nie tylko „miłość podcina własne korzenie", jak powiedziałby Tischner, ale czyni to także wolność, może nawet jeszcze bardziej. Dlatego w oderwaniu od wolności miłość nie mogłaby być sobą, ale chyba też bez miłości i wolność musiałaby ulec jakiemuś przeobrażeniu. Wolność wprowadza dramat w miłość, ale jednocześnie miłością go znosi; bowiem miłość to wybór dobra, opowiedzenie się za prawdą i życie w nadziei. Miłość nigdy nie potępia, lecz wolnością może wznieść człowieka na drogę odnowy.

Myśląc o wolności, nie sposób uniknąć problemu odpowiedzialności. Wyłania się on w zasadzie od razu, gdy jest mowa o wolności, gdyż rzeczywiście odpowiedzialność zakłada wolność, konstytuuje się poprzez nią i dzięki niej „manifestuje” w człowieku. Odpowiedzialność nie tylko odsłania się jako rzeczywistość post factum danej decyzji lub w momencie wybierania, ale jest już obecna pre factum.

Wojtyła i Tischner pojęciu odpowiedzialności przyglądają się z perspektywy aksjologiczno-etyczno-personalistycznej, dostrzegając w nim wielki rezerwuar treści, związanych z wewnętrzną strukturą człowieka, dysponującego swoją wolnością i ukierunkowującego swe działania ku danym wartościom.

Kluczowe analizy Wojtyły dotyczące odpowiedzialności koncentrują się wokół kilku zasadniczych kwestii: odpowiedzialności za wybraną wartość, odpowiedzialności za samego siebie, za dokonanie wyboru wartości oraz za wartość moralną własnej osoby, odpowiedzialności za drugiego, czyli za tego, którego wybiera się i włącza się we wzajemność uczuć i działań (odpowiedzialność w miłości), odpowiedzialności za to, co wnosi się we wzajemność. Wybierając w odpowiedzialności drugiego, wybiera się go jako osobę, ale $\mathrm{w}$ taki sposób, jakby wybierało siebie w drugim i drugiego w sobie.

Każdy z wymienionych problemów stanowi ogromny materiał badawczy, wymagający odrębnych studiów, niemniej można powiedzieć, że problem odpowiedzialności obok pojęcia wolności nie tylko stał się jednym z centralnych w opisie istoty człowieka, ale też że poprzez niego została wyakcentowana dynamiczna rola poszczególnych wolnych czynów człowieka i rola powinności moralnej, przez którą samo zinterpretowanie odpowiedzialności stało się precyzyjniejsze. Wojtyła relację powinności, wolności i odpowiedzialności ujmuje syntetycznie w Osobie i czynie: „Powinność zaś stanowi ową dojrzałą postać odpowiadania na wartości, z którą najbliżej związana 
jest odpowiedzialność. Odpowiedzialność zawiera w sobie coś z powinnościowego odniesienia do wartości. [...] Z racji powinności, znamiennej dla woli, odpowiadanie na wartości przybiera w osobie i jej działaniu postać odpowiadania za wartości. [...] Powinność warunkuje odpowiedzialność, a równocześnie odpowiedzialność jest już jakoś obecna w konstytuowaniu się powinności”29. Wojtyle zależało na podkreśleniu stawania się człowieka w czynach i poprzez czyny. Kiedy jednostka odpowiada na dane wartości, odpowiada tym samym również za nie, tzn. za ich wybór i za wybór w nich samego siebie, i w takim wyborze staje się dobra lub zła. Odpowiedzialność jawi się przede wszystkim jako rzeczywistość wewnątrzosobowa, która określa przede wszystkim najpierw sprawcę czynu. Nie przez samą sprawczość jednak odsłania się odpowiedzialność, lecz poprzez fenomen powinności. Osoba jest odpowiedzialna wówczas, gdy powinna spełnić dany czyn, lub gdy powinna powstrzymać się od spełnienia danego czynu (w zależności od wartości, jakie w danym czynie się prezentują w oczekiwaniu na wybranie). Chodzi w gruncie rzeczy o odpowiedzialność za własną kwalifikację moralną (za kształtowanie siebie od wewnątrz), a następnie za drugiego człowieka, który w polu mojej własnej odpowiedzialności także korzysta $z$ własnej wolności i jakimś w wyborze wartości się staje. Jest się zatem odpowiedzialnym za samego siebie, jak i za drugiego, ale również przed drugim (także Bogiem).

Według Józefa Tischnera odpowiedzialność jest odpowiedzią na potrzebę i pytanie drugiego. Jest to etyczne skierowanie ku drugiemu i od drugiego, który wysyła zapytanie. Odpowiedź realizuje nie tylko wspaniałomyślna miłość, która nie pyta o korzyści, ale również dramatyczna wolność, która niesie w sobie zarówno promil odpowiedzi prawdziwej, jak i promil odpowiedzi fałszywej. W ujęciu Tischnera nie ma prostego przejścia od wolności do odpowiedzialności, ale istnieje rodzaj imperatywu udzielenia odpowiedzi, aby drugiego „nie zabič. Tischner mówi wprost, że „trzeba dać odpowiedź. Nie ma znaczenia, kto pyta - filozof, przechodzień, inkwizytor. Pozostaje tylko twarz. W twarzy, do której mówię, zogniskowała się cała ludzka bieda. To ona prosi, ona mnie poucza" ${ }^{30}$.

Dopiero jednak tam możliwa jest odpowiedzialność, gdzie istnieje możliwość. Gdzie z kolei istnieje możliwość, tam istnieje też wolność. Zarówno wolność, jak i odpowiedzialność mogą się zrealizować w obszarze danych możliwości. Tischner pisze: „cokolwiek człowiek może, może w polu

29 Tenże, Osoba i czyn, dz. cyt., s. 213.

30 J. Tischner, Filozofia dramatu, dz. cyt., s. 76. 
swych możliwości. Pole możliwości jest równoważne polu wolności. Tak więc przestrzeń to w swym zasadniczym rdzeniu stojące przed człowiekiem pole jego sensownej wolności”"

Tam, gdzie wolność daje impuls do odpowiedzi drugiemu, tam może zacząć się wzajemność. Udzielenie odpowiedzi drugiemu w pełnej wolności jest nie tylko zauważeniem jego wartości, ale staje się odpowiedzią na wartości, które wiążą i rodzą zobowiązania. Wartości bowiem mają „ważność” i domagają się uznania. W przestrzeni spotkania i rozmowy aksjologiczna wzajemność Ja i Ty może urzeczywistnić dobro jako najwyższą wartość, nadającą ostatecznie każdej relacji najgłębszy sens.

W poczuciu odpowiedzialności wyraża się w sposób najbardziej źródłowy prawda człowieka. To ono wyróżnia człowieka i wiąże ze światem, ono świadczy o jego wolności i skierowaniu ku wartościom. Odpowiedzialnym można być tylko wobec kogoś ale dzięki wolności, bo w niej ostatecznie „została zaczepiona pajęczyna, po której sączyć się będzie w nasze wnętrze piekło lub niebo, śmierć lub życie, dobro lub zło"32.

Złożoność i wieloaspektowość zagadnienia wolności problematyzuje się tym bardziej, im więcej wątków w myśleniu o człowieku próbuje się przebadać. Upraszczając, oznacza to, iż w jakiejś mierze wolność jest problemem, od którego opis człowieka się zaczyna i do którego zrazu powraca. Poruszone powyżej kwestie zarysowują jedynie przestrzeń, w jakiej można poruszać się, analizując istotę człowieka, ale tej przestrzeni nie ograniczają, choćby $\mathrm{z}$ tego powodu, że mogą intelektualnie poza obręb filozoficznego dyskursu wykraczać do „krajobrazów”, których ani oko nie widziało, ani ucho nie słyszało. Poetyckie określenie Tischnera oznacza po prostu, że dopiero Wolność wszystkich wolności, a więc Bóg oznacza jej pełnię. Wolność skończona i nieskończona wolność Boga spotykają się w osobowej relacji, w osobowej rozmowie i osobowej komunii. Wolność nieskończona nie unicestwia tej skończonej, ale poprzez podarowanie jej człowiekowi wyraża najpełniej szacunek i miłość do poszczególnego wolnego aktu jednostki. Relacja z Drugim, na styku której spotyka się wolność, czyn, miłość i odpowiedzialność, jest zarówno wielkim zadaniem, jak i zaproszeniem do urzeczywistniania siebie nawzajem. Jako zadanie człowiek nieustannie winien siebie zdobywać na nowo, wciąż się odradzać, bo wciąż istnieje pod panowaniem jakiegoś znie-

\footnotetext{
31 Tamże, s. 228.

32 J. Tischner, Jak żyć, Wrocław 1994, s. 14.
} 
wolenia. Wolność rodzi się przez „przebudzenie”, które może płynąć ze strony bliźniego, ale najwyższym budzicielem wolności pozostaje Bóg.

Intelektualna droga Wojtyły i Tischnera z pewnością była wielkim manifestem wolności. Uwydatniała się ona zarówno w przestrzeni słowa pisanego, jak i wygłaszanego. Obydwaj o wolność wołali w dramatycznych momentach dla Polaków, ale i obaj zmagali się z nią na kartach swych publikacji naukowych. Wolność nie była przeto słowem-wytrychem w opisie człowieka, ale słowem kluczem do zrozumienia powołania człowieka ku pełni bycia. Być może nie udało się obu do końca odpowiedzieć na pytanie, czym jest wolność, ale na pewno dostarczają rozmaitych inspiracji intelektualnych kolejnym badaczom.

U obu można odnaleźć intuicję, że spełnienie człowieka wiedzie poprzez wolność, dobro, łaskę, drugiego człowieka, ale syntezą wszystkich syntez staje się miłość, jako zawierzenie się drugiemu, jako bycie darem dla drugiego i rozpoznawanie siebie poprzez drugiego. Ewangeliczne zawołanie: „Jeden drugiego brzemiona noście" (Ga 6, 2a) to jakby złota reguła filozofii Wojtyły i Tischnera, którzy nie tylko w sposób intelektualny próbowali ująć podstawowy wymiar ludzkiego bytowania wśród innych, ale i realnie ową formułę realizowali w swojej służbie innym. 